Primljen / Received: 23.11.2016. Ispravljen / Corrected: 10.4.2017.

Prihvaćen / Accepted: 22.5.2017. Dostupno online / Available online: 10.3.2018.

\section{Physicomechanical properties of concrete mixtures for construction of pavements at bus stations}

Authors:

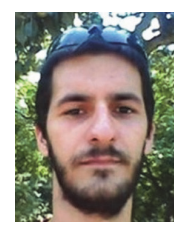

${ }^{1}$ Miloš Šešlija, MSc. CE slavijasrb@gmail.com

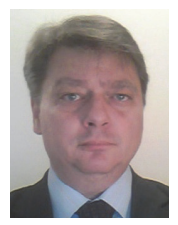

${ }^{1}$ Prof. Nebojša Radović, PhD. CE radovic.nebojsa62@gmail.com

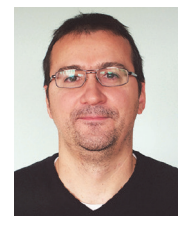

${ }^{1}$ Assist.Prof. Andrija Rašeta, PhD. CE araseta@gmail.com

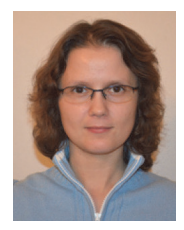

${ }^{1}$ Anka Starčev-Čurčin, MSc. CE astarcev@uns.ac.rs

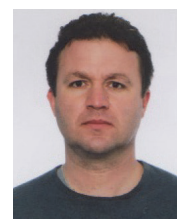

${ }^{2}$ Prof. Danijel Kukaras, PhD. CE danijel.kukaras@gmail.com

1 University of Novi Sad, Faculty of Technical Sciences Department of Civil Engineering and Geodesy

2University of Novi Sad

Faculty of Civil Engineering in Subotica

\author{
Professional paper \\ Miloš Šešlija, Nebojša Radović, Andrija Rašeta, Anka Starčev-Ćurčin, Danijel Kukaras \\ Physicomechanical properties of concrete mixtures for construction of \\ pavements at bus stations
}

A detailed research of three concrete mixtures, used in construction of pavements at bus stations in Novi Sad, is presented in the paper. The mixtures differ by aggregate content, quantity and type of cement, as well as by the type and quantity of additives used for the preparation of concrete mixtures. After examination of physicomechanical properties of concrete, it was established that all mixtures meet the requirements for construction of concrete pavements at bus stations. The obtained results show that the analysed mixtures are also favourable for construction of concrete pavements on roads.

\author{
Key words: \\ concrete pavement, bus stations, physicomechanical properties
}

Stručni rad

Miloš Šešlija, Nebojša Radović, Andrija Rašeta, Anka Starčev-Ćurčin, Danijel Kukaras

\section{Fizikalno-mehanička svojstva betonskih mješavina za izradu kolnika na autobusnim stajalištima}

U radu su prikazana detaljna istraživanja tri betonske mješavine, koje su korištene za izradu autobusnih stajališta u Novom Sadu. Mješavine se razlikuju po udjelu agregata, različitoj količini i tipu cementa, kao i po različitim vrstama i količinama dodataka koji su korišteni za spravljanje betonskih mješavina. Nakon utvrđenih fizikalno-mehaničkih svojstava betona, primijećeno je da sve mješavine ispunjavaju zahtjeve za izgradnju betonskog kolnika za autobusna stajališta. Dobiveni rezultati ukazuju da su analizirane mješavine povoljne i za izradu betonskih kolnika na cestama.

Ključne riječi:

betonski kolnik, autobusna stajališta, fizikalno-mehanička svojstva

Fachbericht

Miloš Šešlija, Nebojša Radović, Andrija Rašeta, Anka Starčev-Ćurčin, Danijel Kukaras

Physikalische und mechanische Eigenschaften der Betonmischungen für die Ausführung von Pflastern an Bushaltestellen

In der Abhandlung werden detaillierte Untersuchungen von drei Betonmischungen dargestellt, die bei der Ausführung von Bushaltestellen in Novi Sad verwendet wurden. Die Mischungen unterscheiden sich durch den Gehalt an Gesteinskörnung, durch die unterschiedliche Zementmenge und -typ, wie auch durch unterschiedliche Arten und Mengen an Zusätzen, die bei der Vorbereitung der Betonmischungen verwendet wurden. Aufgrund der festgestellten physikalischen und mechanischen Eigenschaften des Betons bemerkte man, dass alle Mischungen die Anforderungen für die Ausführung von Betonpflastern für Bushaltestellen erfüllen.

Schlüsselwörter:

Betonpflaster, Bushaltestelle, physikalische und mechanische Eigenschaften 


\section{Introduction}

There are two types of pavement structures: asphalt pavement structure and concrete pavement structure. For flexible road construction, vehicle load is transferred from surface to subgrade based on interaction of grains of granular materials. The effect of this is a low flexural strength of flexible road structures. Flexible pavement structures act as flexible slabs due to load effect. For concrete pavement structures, the load of the vehicle is transmitted as the load that is uniformly distributed over the concrete slab to lower layers, and is then transferred to subgrade through interaction of grains of granular material [1].

Concrete pavement is mainly used in heavy traffic conditions, such as at bus stations, toll booths, gas stations, highways, and tunnels. This type of pavement was for the first time used in Novi Sad in 1994 for bus stations because the asphalt pavement exhibited poor behaviour, as manifested by the occurrence of traps and crevices. After the first concrete pavement was made, it became increasingly popular for construction of other bus stations in Novi Sad. Some 60 bus stations have been built since 1994 , or about $2100 \mathrm{~m}$ in total.

Many authors have shown interest in the study and analysis of concrete pavements. Riffel [2] analysed concrete pavements for production in industrial zones, and for fast repairs of roads and airports. In [2] the author concludes that concrete mixtures tested in the paper meet the physicomechanical requirements for the use of concrete pavements in heavy traffic. Giergiczny [3] cites certain factors relating to the application of concrete pavement, and formulates basic economic indicators with regard to road maintenance and safety. In the end, alternative routes are presented for concrete pavement construction by 2020 in Poland in order to increase the safety and durability of roadways. Some authors [4] investigated frost resistance and compressive strength of concrete pavements.

In this respect, some superplasticisers and air-entraining agents were added to concrete admixtures in order to improve the resistance to frost. A small quantity of silicon dioxide was also added. After the research, it was established that silicon dioxide has a beneficial effect on the behaviour of concrete pavements. Other tests include flexure strength tests $[5,6]$ and sound absorption coefficient test, as well as the resistance to abrasion and tensile strength testing [7]. The splitting tensile strength and shrinkage of concrete pavements were also tested $[8,9]$. In papers [10-16] the authors analysed test results relating to physicomechanical properties of different compositions of concrete mixtures, which was followed by formulation of appropriate correlations between the samples used in the testing.

This paper focuses on laboratory testing of physicomechanical properties of concrete pavements for construction of bus stations using unreinforced concrete with dummy joints (dowels) in transverse direction.
Physicomechanical properties of concrete used in such pavements (compressive strength after 7 and 28 days, flexural strength, resistance to abrasion using both wet and dry methods, density, resistance to cyclic freezing and thawing, resistance to frost and salt, and permeability) enable their use in conditions of very heavy traffic, while also extending pavement life and reducing maintenance costs. The aim of this paper is to examine and compare physicomechanical properties of concrete mixtures for construction of bus stations.

\section{Experimental research}

Two types of cement binders were used for the purposes of this study. The first type of cement, used in $\mathrm{H} 1$ mixtures, is the Portland composite cement with fly ash and limestone (PC 35M (V-L) 42.5R from Beočin). The second type of cement (binder) is the Portland composite cement with granulated slag and limestone (CEM II / AM (SL) 42.5R), which originates from two different manufacturers - LaFarge $(\mathrm{H} 2)$ and Titan Kosjerić (H3)).

The four-fraction natural Moravac river gravel was used as aggregate for bus stations built in the period from 1994 to 2004, while the three-fraction aggregate mixture of the natural Drina river gravel and crushed aggregate from a quarry (Rakovac near Novi Sad) were used for bus stations built in the period from 2010 to the present time. The aggregate grading curves are shown in Figure 1. As illustrated, a smaller fraction of the Moravac natural gravel is outside of the reference range at sieves $0.50,0.25$ and 0.125 by 16 $\%, 4 \%$ and $1 \%$, respectively, while the natural Drina gravel is out of the reference range at sieves 0.25 and 0.125 , by about $1 \%$ in both cases. For the larger size fraction $4 / 8$ of the natural Drina gravel, $4.1 \%$ of oversize grains were retained at sieve 4 , while the Moravac natural gravel has $6 \%$ of oversize grains at sieve 16 for fraction 16/31.5. Quality conditions for particle size distribution were determined according to SRPS B.B2.010 [17] and SRPS B.B3.100 [18].

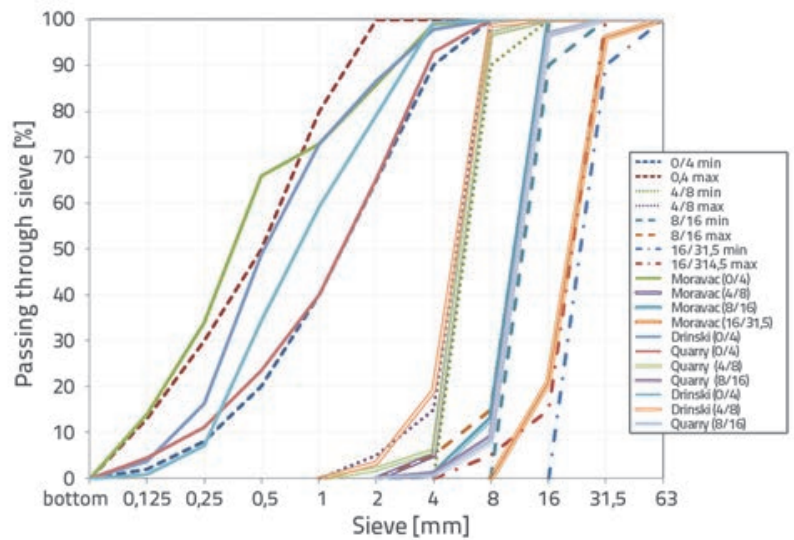

Figure 1. Aggregate grading curves 

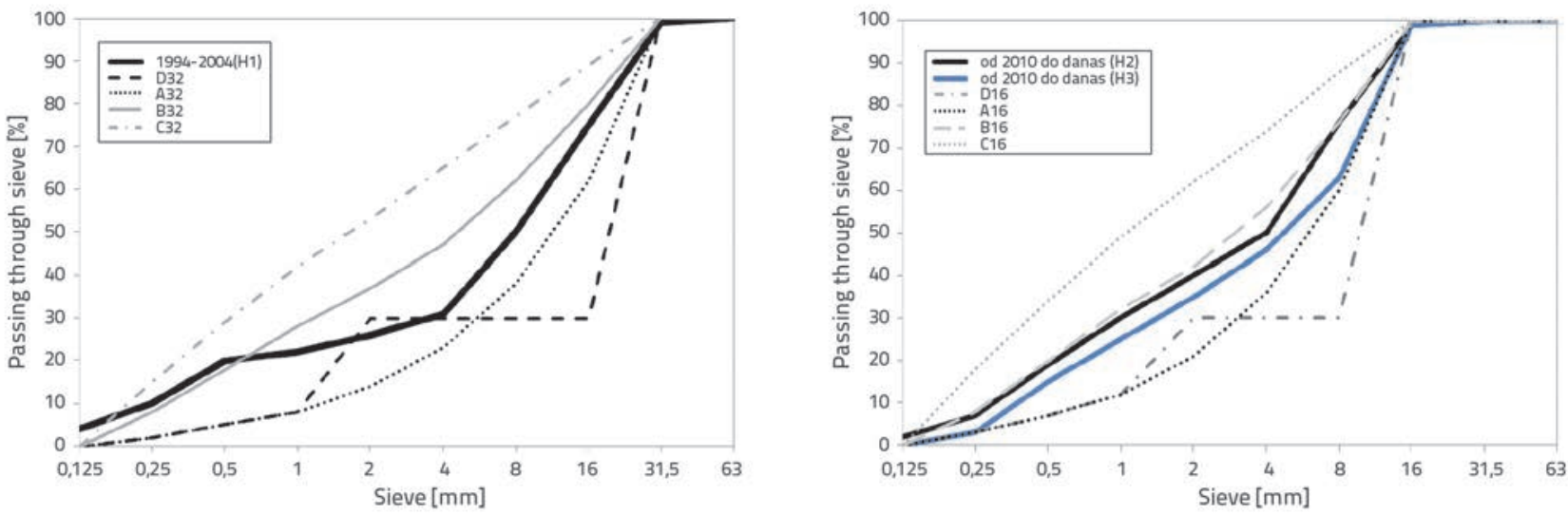

Figure 2. Aggregate grain size distribution with boundary curves for Moravac river gravel (left), and curves for Drina river gravel and crushed stone aggregate (right)

Table 1. Fineness modulus of fine aggregate

\begin{tabular}{|c|c|c|c|}
\hline Sample name (sites) & $\begin{array}{c}\text { Fraction } \\
\text { [mm] }\end{array}$ & $\begin{array}{c}\text { Fineness modulus } \\
{[\%]}\end{array}$ & $\begin{array}{c}\text { Required value of fineness modulus } \\
{[\%]}\end{array}$ \\
\hline Moravac river gravel & \multirow{3}{*}{$0 / 4$} & 2.90 & \multirow{3}{*}{$\min 2.3-\max 3.6$} \\
\hline Drina river gravel & & 3.20 & \\
\hline Crushed stone (Rakovac quarry) & & 2.50 & \\
\hline
\end{tabular}

Table 2. Content of fine particles

\begin{tabular}{|c|c|c|c|c|c|}
\hline \multirow{3}{*}{ Sample name (sites) } & \multirow{3}{*}{$\begin{array}{c}\text { Fraction } \\
\text { [mm] }\end{array}$} & \multicolumn{4}{|c|}{ The content of fine particles [\%] } \\
\hline & & \multicolumn{2}{|c|}{ Examined } & \multicolumn{2}{|c|}{ Required } \\
\hline & & $<0.09 \mathrm{~mm}$ & $<0.063 \mathrm{~mm}$ & $<0.09 \mathrm{~mm}$ & $<0.063 \mathrm{~mm}$ \\
\hline \multirow{4}{*}{ Moravac river gravel } & $0 / 4$ & 1.20 & 0.00 & \multicolumn{2}{|c|}{$\max 5(10) \%$} \\
\hline & $4 / 8$ & 0.90 & 0.10 & \multicolumn{2}{|c|}{$\max 1 \%$} \\
\hline & $8 / 16$ & 0.70 & 0.30 & \multicolumn{2}{|c|}{$\max 1 \%$} \\
\hline & $16 / 31.5$ & 0.40 & 0.20 & \multicolumn{2}{|c|}{$\max 1 \%$} \\
\hline \multirow{3}{*}{ Drina river gravel } & $0 / 4$ & 1.10 & 0.00 & \multicolumn{2}{|c|}{$\max 5(10) \%$} \\
\hline & $4 / 8$ & 0.80 & 0.30 & \multicolumn{2}{|c|}{$\max 1 \%$} \\
\hline & $8 / 16$ & 0.50 & 0.30 & \multicolumn{2}{|c|}{$\max 1 \%$} \\
\hline \multirow{3}{*}{ Crushed stone (Rakovac quarry) } & $0 / 4$ & 1.00 & 0.00 & \multicolumn{2}{|c|}{$\max 5(10) \%$} \\
\hline & $4 / 8$ & 0.80 & 0.20 & \multicolumn{2}{|c|}{$\max 1 \%$} \\
\hline & & 0.60 & 0.40 & \multicolumn{2}{|c|}{$\max 1 \%$} \\
\hline
\end{tabular}

Quality requirements for boundary grading areas were defined as per SRPS U.M1.057 [19]. Boundary curves and adopted mixture curves are shown in Figure 2, where it can be noted that the Moravac natural gravel exhibits deviations in the content of fine particles, while the Drina natural gravel and crushed stone aggregate from a quarry are suitable for construction of concrete pavements.

Apart from grain-size distribution, the following properties were tested: fine-grained aggregate fineness modulus, aggregate fines content, aggregate resistance to crushing (Los Angeles), and stone aggregate resistance to freezing. The fineness modulus for fine-grained aggregate was determined according to SRPS B.B2.010 [17]. The corresponding results are shown in Table 1.

Results for fines content, obtained according to SRPS B.B8.036, are shown in Table 2 [20]. The table shows test results and required values, so that it can be seen whether the content of fine particles is within the specified range according to the standard [20]. The resistance to crushing of natural and crushed stone was tested using the "Los Angeles" method. The results were obtained according to SRPS B.B8.045 [21] as shown in Table 3, where resistance to frost results are also presented. Frost resistance was tested for grain size in excess of $4 \mathrm{~mm}$ according to SRPS B.B8.044 [22]. 
Table 3. Resistance testing for crushed stone aggregate using Los Angeles method and resistance-to-frost testing

\begin{tabular}{|c|c|c|c|c|}
\hline \multirow{2}{*}{ Sample name } & \multicolumn{2}{|c|}{$\begin{array}{l}\text { Resistance of crushed stone aggregate tested } \\
\text { according to Los Angeles method }\end{array}$} & \multicolumn{2}{|c|}{ Resistance to frost of aggregate } \\
\hline & $\begin{array}{l}\text { Tested values } \\
{[\%]}\end{array}$ & $\begin{array}{c}\text { Maximum values } \\
{[\%]}\end{array}$ & $\begin{array}{c}\text { Tested values } \\
{[\%]}\end{array}$ & $\begin{array}{l}\text { Maximum values } \\
{[\%]}\end{array}$ \\
\hline Moravac river gravel & 28.00 & 40.00 & 0.56 & 5.00 \\
\hline Drina river gravel & 27.00 & 40.00 & 0.24 & 5.00 \\
\hline $\begin{array}{l}\text { Crushed stone (Rakovac } \\
\text { quarry) }\end{array}$ & 15.00 & 40.00 & 2.10 & 5.00 \\
\hline
\end{tabular}

Table 4. Parameters defining wearing course of cement-concrete pavements

\begin{tabular}{|c|c|c|c|c|}
\hline \multirow{2}{*}{ Traffic load } & \multicolumn{2}{|c|}{$\begin{array}{l}\text { Resistance to crushing for stone aggregate } \\
\text { (Los Angeles) }\end{array}$} & \multicolumn{2}{|c|}{$\begin{array}{c}\text { Resistance to frost for stone aggregate grain siz } \\
\text { of over } 4 \mathrm{~mm}\end{array}$} \\
\hline & $\begin{array}{l}\text { Tested samples } \\
{[\%]}\end{array}$ & $\begin{array}{l}\text { Maximum values } \\
{[\%]}\end{array}$ & $\begin{array}{l}\text { Tested samples } \\
{[\%]}\end{array}$ & $\begin{array}{l}\text { Maximum values } \\
{[\%]}\end{array}$ \\
\hline Very heavy & \multirow{3}{*}{15.00} & 16.00 & \multirow{3}{*}{2.10} & \multirow{3}{*}{3.00} \\
\hline Heavy & & 18.00 & & \\
\hline Other & & 22.00 & & \\
\hline
\end{tabular}

It can be seen that all aggregates are compliant with Technical Requirements. Prescribed aggregate properties for production of concrete mixtures, as applied to wearing courses for cementconcrete pavements, were also determined according to the standard [23]. Test results for limit values are given in Table 4. Stone aggregate test results comply with requirements given in the standard [23]. Bus stations built in the period from 1994 to 2004 do not comply with required aggregate properties for cement-concrete pavement wearing courses for all types of traffic load, because the aggregate must contain at least $50 \%$ of grains in excess of $8 \mathrm{~mm}$. River aggregate is better in terms of workability and machinability, and crushed stone aggregate has a higher roughness and contributes to better physicomechanical properties of concrete mixes.

Tab water was used for concrete mixtures, and a certain amount of additives was added. The mixture $\mathrm{H} 1$ (1994 - 2004) differs as to the type of cement and aggregate. For the aggregate, four-fraction Moravac natural gravel was used, while another type of cement was used for the $\mathrm{H} 2$ mixture (2010 - today). Natural Drina gravel was used for the first fraction aggregate $(0 / 4 \mathrm{~mm})$ in the amount of $30 \%$, while the other $20 \%$ of the first fraction $(0 / 4 \mathrm{~mm})$ was crushed stone aggregate. The second $(4 / 8 \mathrm{~mm})$ and third $(8 / 16 \mathrm{~mm})$ fractions were made of crushed stone aggregate from Rakovac quarry. The H3 mixture (2010 today) is made of the same type of cement as the $\mathrm{H} 2$ mixture, but from another producer, while the natural Drina gravel was used for the first fraction $(0 / 4 \mathrm{~mm})$ and the second fraction $(4 / 8 \mathrm{~mm})$. The crushed stone aggregate from quarry was used for the third $(8 / 16 \mathrm{~mm})$ fraction. Approximate compositions of concrete mixtures $\mathrm{H} 1, \mathrm{H} 2$ and $\mathrm{H} 3$ are shown in Table 5.

Three mixtures in total were prepared with different aggregates, different types of cement, water and additives. Relevant standards were changed since 1994, and the JUS standard was transposed to SRPS. At the time of preparation of $\mathrm{H} 1$ mixtures, the compressive strength was tested on $20 \times 20 \times 20 \mathrm{~cm}$ cubes according to JUS U.M1.020 [24]. However,

Table 5. Material proportions for $1 \mathrm{~m} 3$ of concrete

\begin{tabular}{|c|c|c|c|c|c|c|c|}
\hline \multicolumn{2}{|c|}{ Mixture ingredients $\left[\mathrm{kg} / \mathrm{m}^{3}\right]$} & \multicolumn{2}{|c|}{ H1 } & \multicolumn{2}{|c|}{$\mathrm{H} 2$} & \multicolumn{2}{|c|}{ H3 } \\
\hline \multicolumn{2}{|c|}{ Cement } & \multicolumn{2}{|c|}{ a) 420.00} & \multicolumn{2}{|c|}{ b) 400.00} & \multicolumn{2}{|c|}{ c)/31.00 } \\
\hline \multirow{4}{*}{ Aggregate } & $0 / 4$ & $30 \%$ & \multirow{4}{*}{1776.00} & $50 \%$ & \multirow{4}{*}{1796.00} & $43 \%$ & \multirow{4}{*}{1727.00} \\
\hline & $4 / 8$ & $18 \%$ & & $24 \%$ & & $17 \%$ & \\
\hline & $8 / 16$ & $20 \%$ & & $26 \%$ & & $40 \%$ & \\
\hline & $16 / 31.5$ & $32 \%$ & & - & & - & \\
\hline \multicolumn{2}{|c|}{ Additive 1} & \multicolumn{2}{|c|}{ (Reobet aerant) 0.80} & \multicolumn{2}{|c|}{ (Sika viscoCrete 3070) 3.60} & \multicolumn{2}{|c|}{ (Fluiding M1M. Ading) 5.18} \\
\hline \multicolumn{2}{|c|}{ Additive 2} & \multicolumn{2}{|c|}{ (Reobet SPRD 80) 4.20} & \multicolumn{2}{|c|}{ (Sika Aer) 0.05} & \multicolumn{2}{|c|}{ (Pročinitelj. Ading) 0.39} \\
\hline \multicolumn{2}{|c|}{ Water } & \multicolumn{2}{|c|}{170.00} & \multicolumn{2}{|c|}{170.00} & \multicolumn{2}{|c|}{166.00} \\
\hline \multicolumn{2}{|c|}{ Water-cement ratio } & \multicolumn{2}{|c|}{0.405} & \multicolumn{2}{|c|}{0.425} & \multicolumn{2}{|c|}{0.384} \\
\hline
\end{tabular}


the compression strength for $\mathrm{H} 2$ and $\mathrm{H} 3$ was tested on $15 \times 15 \times 15 \mathrm{~cm}$ cube samples according to SRPS ISO 4012. A conversion coefficient of 0.95 was defined in order to compare test results, i.e. so that the samples tested using $20 \times 20 \times$ $20 \mathrm{~cm}$ cubes can be compared with the results obtained on samples measuring $15 \times 15 \times 15 \mathrm{~cm}$ [25].

The following physicomechanical properties of concrete pavements were tested:

- compressive strength;

- flexural strength;

- density;

- abrasion resistance;

- determination of water penetration under pressure;

- resistance to frost;

- resistance to frost and salts.

\subsection{Compressive strength}

The compressive strength is defined as an average stress in the sample subjected to axial pressure at breaking force, for a certain age of concrete. The compressive strength test was carried out on concrete cubes $20 \times 20 \times 20 \mathrm{~cm}$ or 15 $\times 15 \times 15 \mathrm{~cm}$, after which the concrete grade was defined. Samples were cured in a humid chamber and tested after 7 and 28 days. The compressive strength test was conducted according to JUS U.M1.020 [24] for hardened concrete mixtures from 1994-2004 (H1), and according to ISO 4012 2000 [26] for concrete mixtures from the year 2010 to this day ( $\mathrm{H} 2$ and $\mathrm{H} 3)$.

\subsection{Flexural strength}

The flexural strength was tested on concrete prisms measuring $10 \times 10 \times 40 \mathrm{~cm}$, which were cured for 28 days in humid chamber. The flexural strength test was performed according to U.M1.010 [27] for the concrete mix H1, or according to ISO 4013: 2000 [28] for concrete mixtures H2 and H3.

\subsection{Abrasion resistance}

The abrasion resistance is one of the key elements when testing concrete pavement for bus stations. The abrasion resistance is tested on concrete cubes measuring $7.1 \times 7.1 \times 7.1$ $\mathrm{cm}$ using the so-called dry procedure in which the maximum loss of mass can not be greater than $18 \mathrm{~cm}^{3} / 50 \mathrm{~cm}^{2}$, or using the wet procedure, where the maximum permissible loss is 35 $\mathrm{cm}^{3} / 50 \mathrm{~cm}^{2}[29]$.

\subsection{Determination of water penetration under pressure}

Testing water penetration under pressure depends on the degree of cement hydration, porosity of the cementitious stone, pore structure, and properties of cements and individual aggregates. The water permeability of concrete is defined through waterproofing labels, and by using the method with free lateral penetration of water. These labels are $\mathrm{V}-2, \mathrm{~V}-4, \mathrm{~V}-6, \mathrm{~V}-8$, and $\mathrm{V}-12$, with the numbers indicating pressure in bars. The test was carried out on $15 \times 15 \times 15 \mathrm{~cm}$ cube samples. Concrete is considered to be watertight if the deformation depth is less than $5 \mathrm{~cm}$ [30].

\subsection{Resistance to frost}

Frost resistance is the ability of concrete to withstand cyclic freezing and thawing in the water saturated state. It was determined on $15 \times 15 \times 15 \mathrm{~cm}$ [31] cube samples, with the test being carried out at every 50 cycles in order to obtain maximum accuracy of results. The preliminary test for concrete pavement was carried out in 250 cycles. If the compressive strength loss is over $25 \%$, it is considered that concrete pavement is not resistant to frost.

\subsection{Resistance to frost and salts}

Resistance to the influence of frost and salts was determined by cyclic freezing and thawing. A frame with salt solution ( $\mathrm{NaCl}$, maintained at $3 \mathrm{~mm}$ above sample surface until the testing, was placed on the surface of the sample. The sample exposure method is precisely defined in SRPS U.M1.055 [32]. After 25 cycles, the loss of mass was measured, and the depth of surface peeling of sample subjected to the influence of salt was determined. After the testing, the group of concrete pavement was determined according to SRPS U.E3.020 [23].

\section{Results and discussion}

Statistical analysis of results obtained by testing physicomechanical properties after 7 and 28 days is shown in Table 6, and the results of frost resistance, frost and salt resistance, and the values of the water penetration under pressure test are shown below. The compressive strength values obtained for the $\mathrm{H} 1$ mixture are divided by conversion factor to obtain compressive strength values for concrete cubes measuring $15 \times 15 \times 15 \mathrm{~cm}$. Three different types of concrete mixtures were prepared, for each of the previously tested three series of test samples. Since the first mixture was made in the period from 1994 to 2004, a total of 30 cubes were produced for that period, i.e. the mixture contains three samples for the compressive strength test for each year. Compressive strength values for I, II and III series of 10 samples varied within \pm 0.3MPa. Samples made during the period from 2010 to 2016 were not tested every year but periodically (every 1.5 years), i.e. samples for compressive strength after 7 and 28 days were made before the concrete pavement was built on bus stations. The flexural strength and abrasion resistance tests (dry and wet method) were performed periodically for all mixtures (every 2 years) and a total of 27 samples were tested, i.e. a total of 15 
samples were tested for the $\mathrm{H} 1$ mixture, and 6 samples per mixture were tested for $\mathrm{H} 2$ and $\mathrm{H} 3$ mixtures. The arithmetic value (mean value) of the samples was determined according to equation (1).

$$
\bar{x}=\frac{\sum_{i=1}^{n} x_{i}}{n}
$$

where:

$\bar{x}$ - arithmetic value of $\mathrm{n}$ test results

$x_{i}$ - value of each sample of $n$ results

$n$ - number of samples.

The standard deviation value is determined according to equation (2):

$\sigma=\sqrt{\frac{\sum_{i=1}^{n}\left(x_{i}-\bar{x}\right)^{2}}{n}}$

where:

$\sigma$ - standard deviation

$\bar{x}$ - arithmetic value of $\mathrm{n}$ test results $x_{i}$ - value of each sample of $n$ results

n - number of samples.

The coefficient of variation $\left(C_{v}\right)$ is determined by equation (3), where it is primarily necessary to calculate the standard deviation.

$C_{v}=\frac{\sigma}{\bar{X}}$

where:

$C_{v}$ - coefficient of variation

$\sigma$ - standard deviation

$\bar{x}$ - arithmetic value of $\mathrm{n}$ test results.

Mean values, standard deviations, and variation coefficients obtained by testing are shown in Table 6. These statistical data also serve to determine the deviation from arithmetic value of the set, as well as to show variability, i.e. whether it belongs to a homogeneous or heterogeneous set $\left(C_{v}<30 \%\right.$ homogeneous set, $C_{v}>30 \%$ heterogeneous set), or whether variability is significantly lower than its arithmetic value. According to test results, the standard deviation complies with all requirements except for the density testing where

Table 6. Mean value, standard deviation and coefficient of variation for hardened concrete samples

\begin{tabular}{|c|c|c|c|c|}
\hline \multirow{2}{*}{\multicolumn{2}{|c|}{ Properties of hardened concrete }} & \multicolumn{3}{|c|}{ Concrete mixtures } \\
\hline & & \multirow{2}{*}{ H1 } & \multirow{2}{*}{$\frac{\mathrm{H} 2}{41.07}$} & \multirow{2}{*}{ H3 } \\
\hline \multirow{3}{*}{ 7-day compressive strength of concrete [MPa] } & $\bar{x}$ & & & \\
\hline & $\sigma$ & 1.50 & 0.85 & 1.10 \\
\hline & $C_{v}$ & 3.94 & 2.07 & 2.70 \\
\hline \multirow{3}{*}{ 28-day compressive strength of concrete [MPa] } & $\bar{x}$ & 48.2 & 52.9 & 53.03 \\
\hline & $\sigma$ & 2.05 & 3.34 & 3.45 \\
\hline & $C_{v}$ & 4.26 & 6.32 & 6.51 \\
\hline \multirow{3}{*}{ 28-day concrete flexural strength [MPa] } & $\bar{x}$ & 6.73 & 6.87 & 6.67 \\
\hline & $\sigma$ & 0.42 & 0.15 & 0.15 \\
\hline & $C_{v}$ & 6.18 & 2.22 & 2.29 \\
\hline \multirow{3}{*}{ 28-day density of hardened concrete $\left[\mathrm{kg} / \mathrm{m}^{3}\right]$} & $\bar{x}$ & 2398.00 & 2381.00 & 2362.00 \\
\hline & $\sigma$ & 11.55 & 12.12 & 13.61 \\
\hline & $C_{v}$ & 0.48 & 0.51 & 0.58 \\
\hline \multirow{3}{*}{ Abrasion resistance ${ }^{*}\left[\mathrm{~cm}^{3} / 50 \mathrm{~cm}^{2}\right]$} & $\bar{x}$ & 14.77 & 13.4 & 10.37 \\
\hline & $\sigma$ & 1.12 & 0.95 & 1.93 \\
\hline & $C_{v}$ & 7.55 & 7.12 & 18.61 \\
\hline \multirow{3}{*}{ Abrasion resistance ${ }^{* *}\left[\mathrm{~cm}^{3} / 50 \mathrm{~cm}^{2}\right]$} & $\bar{x}$ & 31.67 & 29.00 & 21.03 \\
\hline & $\sigma$ & 1.99 & 2.49 & 0.57 \\
\hline & $C_{v}$ & 6.27 & 8.58 & 2.70 \\
\hline \multicolumn{5}{|c|}{$\begin{array}{l}\text { *Abrasion resistance for dry samples; }{ }^{* *} \text { Abrasion resistance for wet samples; } \\
\bar{x} \text { - Arithmetic value; } \sigma \text { - Standard deviation; H1 - Concrete mixtures in the period } 1994 \text { to 2004; } \\
\text { H2 i H3 - Concrete mixtures in the period } 2010 \text { to today; } C_{v}-\text { Coefficient of variation }\end{array}$} \\
\hline
\end{tabular}


Table 7. Characteristics of concrete mix composition

\begin{tabular}{|c|c|c|c|c|c|}
\hline $\begin{array}{l}\text { No. } \\
\text { Paper }\end{array}$ & Type of aggregate & Fraction $[\mathrm{mm}]$ & Binder type & $\begin{array}{c}\text { Chemical and/or mineral } \\
\text { additives }\end{array}$ & Water-cement ratio $\left(\mathrm{m}_{\mathrm{v}} / \mathrm{m}_{\mathrm{c}}\right)$ \\
\hline [4] & - & $0-20$ & portland cement & $\begin{array}{c}\text { aerates, nanosilicate, high } \\
\text { degree of water reduction } \\
\text { (HRWR) }\end{array}$ & $0.39-0.45$ \\
\hline \multirow{2}{*}{ [5] } & limestone & \multirow{2}{*}{$0-10$} & \multirow{2}{*}{ portland cement } & \multirow{2}{*}{-} & \multirow{2}{*}{0.52} \\
\hline & recycled concrete & & & & \\
\hline [11] & river aggregate & $0-16$ & CEM I 42.5R & $\begin{array}{c}\text { fly ash, polypropylene fibres, } \\
\text { plasticizers }\end{array}$ & 0.35 \\
\hline \multirow{3}{*}{ [13] } & granite & \multirow{3}{*}{$0-20$} & \multirow{3}{*}{ portland cement } & \multirow{3}{*}{-} & \multirow{3}{*}{$0.39-1.35$} \\
\hline & slag & & & & \\
\hline & sand & & & & \\
\hline \multirow{2}{*}[14]{} & gravel & \multirow{2}{*}{$0-20$} & \multirow{2}{*}{ portland cement } & \multirow{2}{*}{ fly ash, silicate dust } & \multirow{2}{*}{$0.36-0.40$} \\
\hline & sand & & & & \\
\hline \multirow{2}{*}{ [15] } & sand & \multirow{2}{*}{$0-12.5$} & \multirow{2}{*}{$\begin{array}{l}\text { CEM } \| 32.5 \mathrm{~N} \\
\text { CEM } \| 42.5 \mathrm{~N}\end{array}$} & \multirow{2}{*}{-} & \multirow{2}{*}{$0.46-0.60$} \\
\hline & recycled concrete & & & & \\
\hline \multirow{2}{*}[16]{} & crushed stone & \multirow{2}{*}{$0-12.5$} & \multirow{2}{*}{ portland cement } & \multirow{2}{*}{-} & \multirow{2}{*}{$0.25-0.35$} \\
\hline & sand & & & & \\
\hline \multirow{4}{*}{ [33] } & granite & \multirow{4}{*}{-} & \multirow{4}{*}{ CEM I } & \multirow{4}{*}{$\begin{array}{l}\text { aerates, fly ash, retarders, } \\
\text { superplasticizer }\end{array}$} & \multirow{4}{*}{0.30} \\
\hline & limestone & & & & \\
\hline & river aggregate & & & & \\
\hline & sand & & & & \\
\hline \multirow{3}{*}{ [34] } & limestone & \multirow{3}{*}{$0-25$} & \multirow{3}{*}{ portland cement } & \multirow{3}{*}{ electrofilters ashes, aerates } & \\
\hline & recycled concrete & & & & $0.37-0.42$ \\
\hline & sand & & & & \\
\hline & crushed stone & & netlond smot & & \\
\hline [35] & sand & - & portland cement & aerates, superplastıcızer & 0.30 \\
\hline$[36]$ & limestone & & notlond comont & nompor & $021-21$ \\
\hline$[30]$ & sand & - & portadic ceminemi & deldies & $0.21-0.34$ \\
\hline
\end{tabular}

standard deviation values are much higher compared to other samples. The coefficient of variation values are lower, and all results belong to the group of homogeneous sets, i.e. variables are significantly lower than own arithmetic value. The compressive strength of the $\mathrm{H} 1$ mixture at 7 and 28 days amounts to $38.03 \mathrm{MPa}$ and $48.2 \mathrm{MPa}$, respectively. Values obtained for the $\mathrm{H} 2$ mixture, cured in humid chamber, attain 41.07 MPa and 52.9 MPa at 7 and 28 days, respectively. The $\mathrm{H} 3$ mixes attain the compressive strength of $40.67 \mathrm{MPa}$ and 53.03 MPa after 7 and 28 days, respectively. The decrease in the $\mathrm{H} 1$ mixture compressive strength amounts to about $8 \%$ in relation to the $\mathrm{H} 2$ mixture at 7 days, i.e. about $10 \%$ at 28 days. Obviously, the composition of the mixture (type of aggregate, fraction percentage, water-cement ratio, and additives) has an effect on changes in the results when physicomechanical properties are tested.

Experimental results were compared with literature data, i.e. the following physicomechanical properties of hardened concrete mixtures were compared:
- compressive strength after 7 and 28 days

- flexural strength after 28 days

- density of hardened concrete after 28 days

- abrasion resistance according to dry process.

Beside the basic components, chemical and/or mineral additives are added to meet higher requirements for fresh and hardened concrete. Properties of concrete mixtures for pavements from the analysed literature are shown in Table 7.

\subsection{Compressive strength}

Compressive strength values for samples at the age of 7 days are shown in Figure 3 - left. Labels I, II, and III denote the mean value of the series of samples, which is to be compared later on with other mixtures. It can be seen that the $\mathrm{H} 1$ mixture samples have lower compressive strength values as compared to $\mathrm{H} 2$ and $\mathrm{H} 3$ samples. The maximum values of compressive strength were registered at the $\mathrm{H} 2$ 

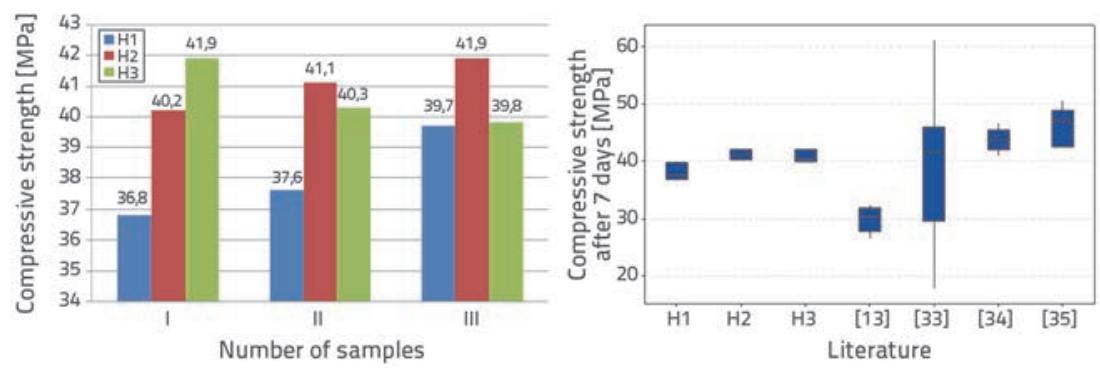

Figure 3. Compressive strength at 7 days (left) and comparative tensile strength results at 7 days (right)
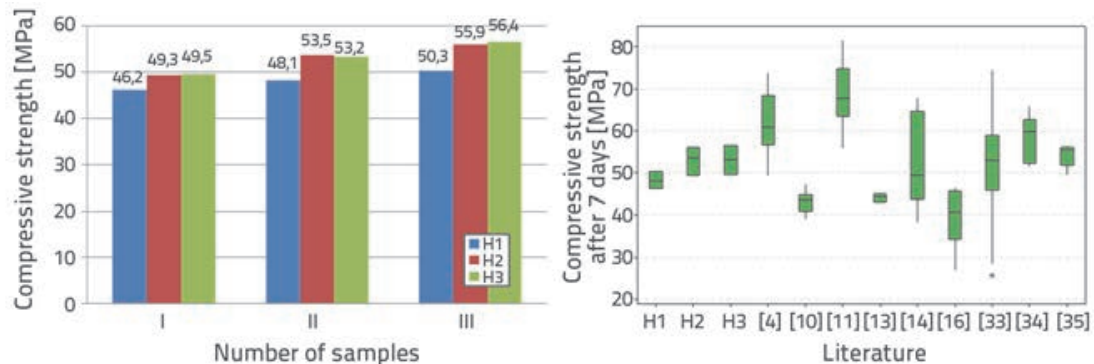

Figure 4. Compressive strenght at 28 days
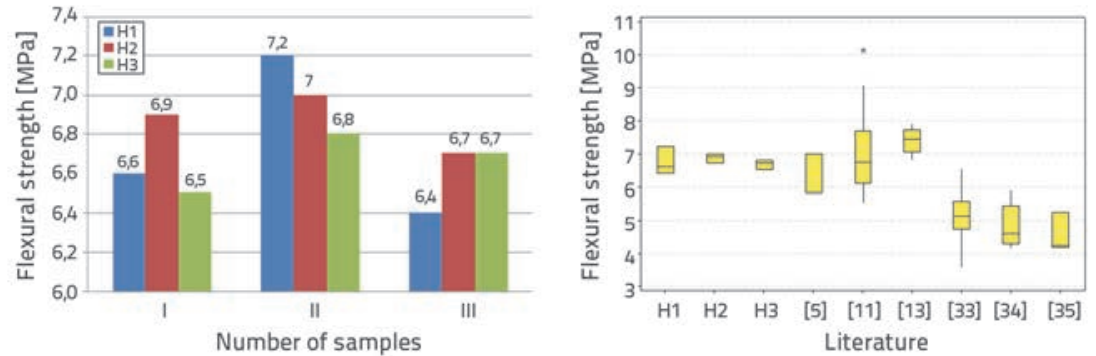

Figure 5. Flexural strength
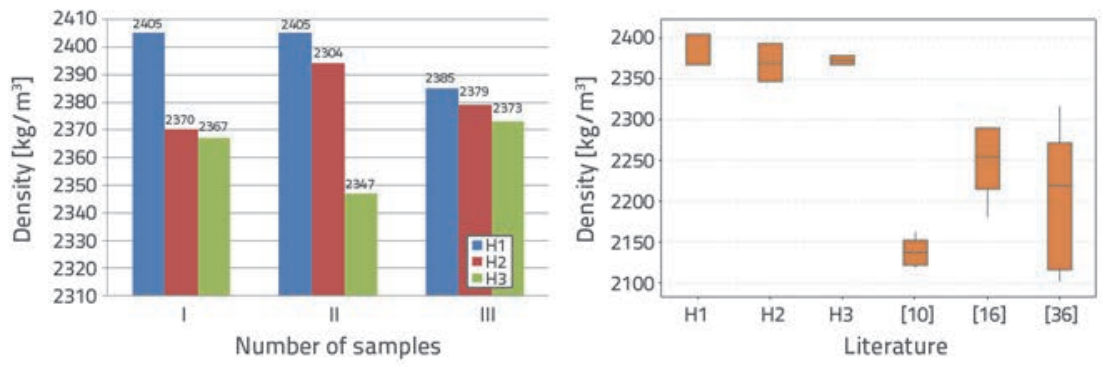

Figure 6. Density data aggregates, and also due the type of cement used for the production of concrete mixtures $\mathrm{H} 2$ and $\mathrm{H} 3$. Maximum values were achieved at mixtures $\mathrm{H} 2$ and $\mathrm{H} 3$, while minimum values were achieved at the $\mathrm{H} 1$ mixture. The deviation of results between the mixtures is approximately $10 \%$. Compared to literature data (Figure 4 - right), the tested mixtures are characterised by the mediocre value of compressive strength because the dispersion results range from about 25 to $82 \mathrm{MPa}$.

\subsection{Flexural strength}

Flexural strength values after 28 days were also determined (Figure 5). It can be noticed that flexural strength trends are not similar to the trends obtained for compressive strength after 28 days. Maximum flexural strength values were achieved at the $\mathrm{H} 2$ mixture. Approximate flexural strength values were obtained at the $\mathrm{H} 2$ mixture (Figure 5 - left). Other authors have obtained variable values of flexural strength, in a large range (3.5-10 $\mathrm{MPa})$, while in the tested mixtures $\mathrm{H} 1$, $\mathrm{H} 2$, and $\mathrm{H3}$ the dispersion of results is not high. Results obtained for the tested mixtures are quite favourable for concrete pavement structures compared to conclusion given in literature (Figure 5 - right).

After presentation of compressive strength and flexural strength values, it can be noticed that minimum heavy traffic load criteria for compressive and flexural strength according to SRPS U.E3.020 [23] have been satisfied. The minimum concrete class values, as well as the flexural strength values, are shown in Table 8. sample. In comparison to other papers, the tested mixtures have a mediocre value of compressive strength. The minimum values of compressive strength compared to the other test mixtures were achieved in papers [13, 33] (Figure 3 - right).

A significant increase in compressive strength was registered at 28 days (Figure 4 - left). The compressive strength of concrete increases due to the combination of the river and crushed aggregates, i.e. the participation of the three-fraction
Table 8. Required compressive strength values (MB) and flexural strength values for traffic load [23]

\begin{tabular}{|c|c|c|}
\hline Predicted traffic load & $\begin{array}{c}\text { Compressive } \\
\text { strength }[\mathrm{MPa}]\end{array}$ & $\begin{array}{c}\text { Flexural strength } \\
\mathbf{f}_{\mathbf{z s}}[\mathrm{MPa}]\end{array}$ \\
\hline Very heavy & 40 & 5.0 \\
\hline Heavy & 35 & 4.5 \\
\hline Other & 30 & 4.0 \\
\hline
\end{tabular}




\subsection{Density}

Density test results for solid concrete samples after 28 days are shown in Figure 6 - left. Maximum density values were obtained at the $\mathrm{H}_{1}$, and minimum ones at the $\mathrm{H} 3$ mixture. Compared to other literature data $[10,16,36]$, the tested mixtures show maximum values, while minimum density values are provided in papers [10,36] (Figure 6 on the right). The dissipation of test results $\left(\mathrm{H}_{1}, \mathrm{H}_{2}\right.$ and $\left.\mathrm{H}_{3}\right)$ is generally quite low.

\subsection{Abrasion resistance}

Abrasion resistance values for dry procedure are shown in Figure 7 (left), while the corresponding wet test results are shown in Figure 7 (right).

The abrasion resistance test was performed by wearing off the abrasive layer using the scrubbing test at 28 days according to [28]. After that, it was determined according to [29] where it is specified that the mass loss must not exceed $18 \mathrm{~cm}^{3} / 50 \mathrm{~cm}^{2}$ in dry state or $35 \mathrm{~cm}^{3} / 50 \mathrm{~cm}^{2}$ in the water saturated state.

It can be noticed that the $\mathrm{H} 3$ samples have a lower mass loss for both types of tests. The maximum values for sample mass loss at 28 days meet the requirements for production of concrete pavements according to $[23,29]$. The $\mathrm{H} 1$ mixtures have critical values for the wet abrasion resistance test.
Figure 8 shows comparison between experimental abrasion resistance results obtained by dry method and literature data. The obtained results comply with abrasion resistance criteria, except for paper [16] where most of the results exceed the required standard values $[23,29]$.

\subsection{Resistance to frost}

Resistance to frost is shown in Figure 9, where it can be seen that the losses per 100 and 150 cycles are approximately the same. Then, there is a significant loss of compressive strength for concrete mixtures.

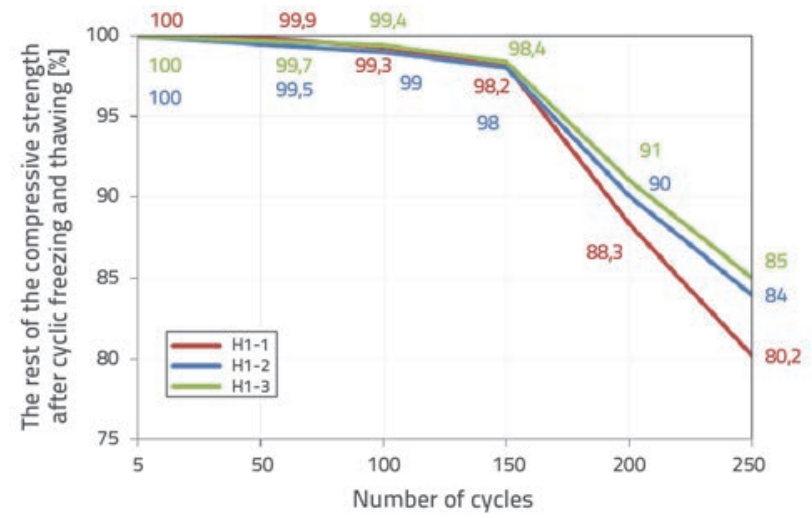

Figure 9. Frost resistance
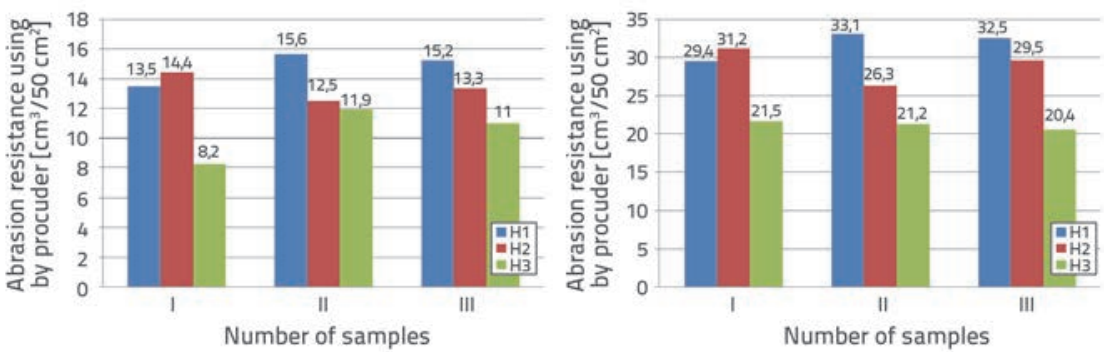

Figure 7. Abrasion resistance using dry procedure (left) and wet procedure (right)

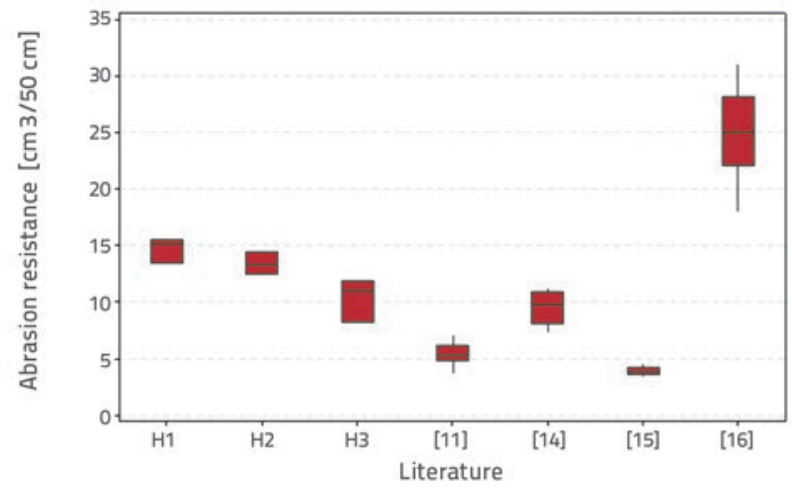

Figure 8. Abrasion resistance by dry method
All analysed mixtures meet the requirements, as the loss of compressive strength is less than $25 \%$ [31]. The only difference in this study compared to standard [31] is that six samples were made for each of the 50 test cycles, three of which were reference samples stored in humid chamber, while the other three were exposed to cyclic freezing and thawing.

\subsection{Resistance to frost and salts}

Test results for frost and salts resistance are shown in Figure 10. Mass losses are negligibly low for all three mixtures $(H 1$, $\mathrm{H} 2$ and $\mathrm{H} 3$ ), and so there is no deformation depth in the tested samples. Based on the test results, it can be concluded that concrete samples tested according to standard [30] have a degree of damage of " 0 " after 25 cycles, i.e. the tested samples are resistant to the influence of frost and salt. 

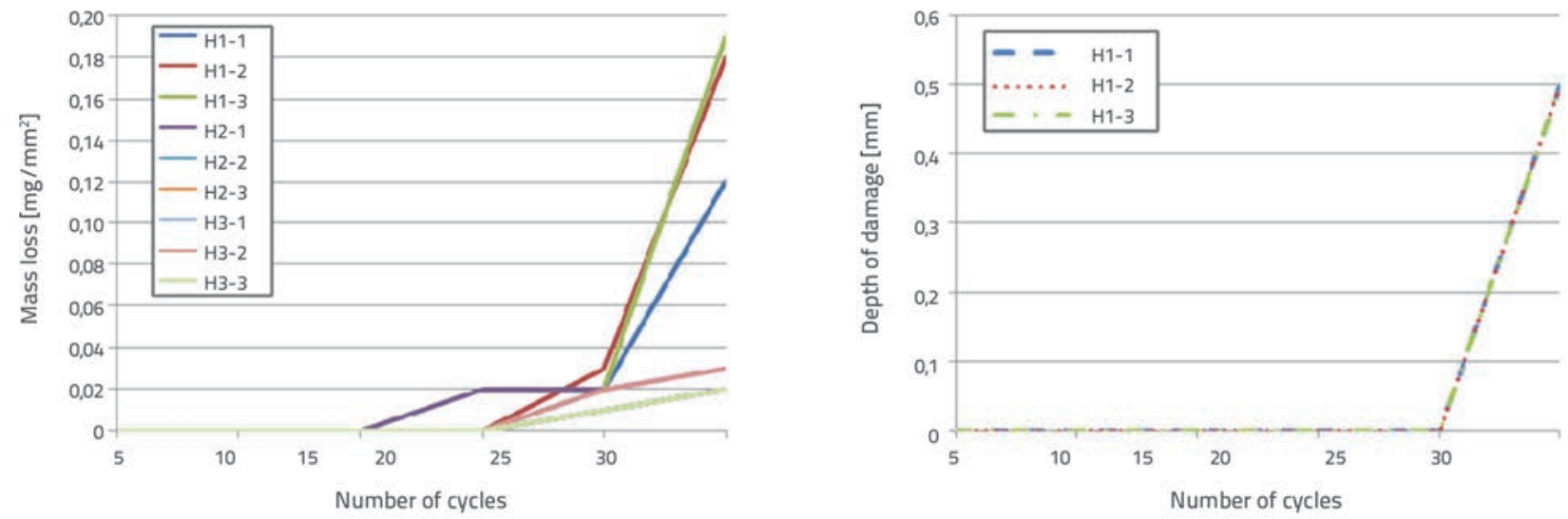

Figure 10. Resistance to frost and salts; mass loss (left) and depth of damage (right)
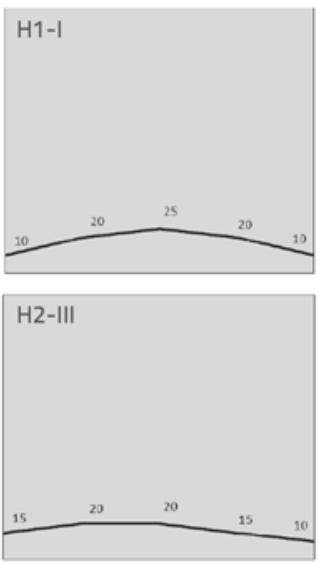
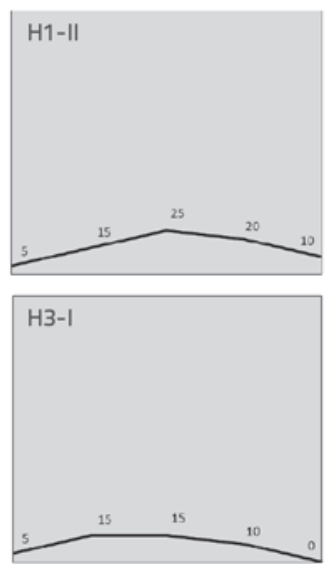
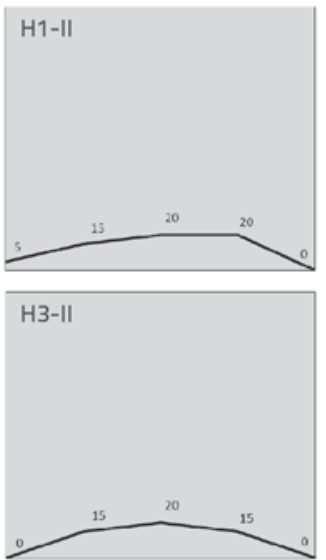
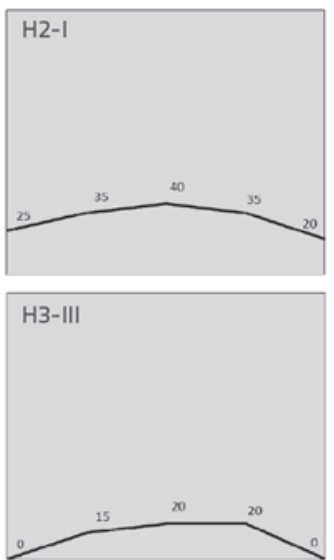

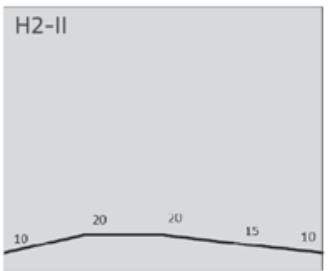

Figure 11. Graphical presentation of results for penetration of water under pressure

\subsection{Determination of water penetration under pressure}

Penetration of water under pressure was tested according to standards presented in [23,30]. Technical conditions given in [23] define that the minimum class must not be lower than V6 for the concrete directly exposed to atmospheric impacts. According to test results given in Figure 11, it can be seen that water permeability at the $\mathrm{H} 2$ mixture is higher than the corresponding values for $\mathrm{H} 1$ and $\mathrm{H} 3$ mixtures. All tested mixtures meet the requirements because the water penetration is less than $5 \mathrm{~cm}$.

\section{Conclusion}

The following conclusions can be made based on research conducted in the scope of this paper:

- According to the grain size distribution for the Moravac river gravel, this gravel contains some grains that are out of the reference region for the small fraction $(0 / 4 \mathrm{~mm})$ and large fraction $(16 / 31.5 \mathrm{~mm})$ aggregates, while the $\mathrm{H} 3$ mixture grading reveals a lower quantity of grains that are out of the reference region for the small fraction $(0 / 4 \mathrm{~mm})$ aggregate;

- by analysing aggregate properties according to SRPS U.E3.020, it can be concluded that the Moravac natural gravel does not comply with the minimum $50 \%$ fraction of crushed stone for fractions above $8 \mathrm{~mm}$, while the properties of the crushed stone aggregate and the natural Drina gravel are in accordance with the requirements;

- tested mixtures $\mathrm{H}_{1}, \mathrm{H} 2$ and $\mathrm{H} 3$ comply with all requirements regarding physicomechanical properties of hardened concrete for pavement construction at bus stations, with the $\mathrm{H} 3$ mixture having significantly better properties compared to the other two mixtures;

- compared to literature data, the tested mixtures exhibit mediocre compressive strength values because mineral additives were not used in tested mixtures to increase the compressive strength, as was the case in some literature data where maximum values were obtained;

- the results regarding flexural strength, density, and abrasion resistance using dry process represent maximum values because no mineral additives were added.

After presentation of results, it can generally be concluded that the $\mathrm{H} 1$ mixture used in the 1994-2004 period, and the mixtures currently in use ( $\mathrm{H} 2$ and $\mathrm{H} 3)$ for the production of concrete pavement on bus stations, are also suitable for other roadways. Therefore, the aim is to promote the use of concrete pavements because of their higher bearing capacity and durability as compared to asphalt pavements. 


\section{Acknowledgements}

The authors extend their thanks to the Ministry of Science and Technology Development of the Republic of Serbia for its assistance, within the Technology Project TR 36017, in the realisation of the research entitled: Study of possible uses of waste and recycled materials in concrete composites with the assessment of environmental impacts, aimed at promoting sustainable civil engineering in Serbia, a part of which is presented in this paper.

\section{REFERENCES}

[1] Pozder, M.: Fleksibilna naspram krutih kolovoznih konstrukcija, Simpozijum Betonske saobraćajnice, Sarajevo, pp. 37-45, 2015.

[2] Riffel, S.: Posebna rješenja za saobraćajnice na bazi hidrauličkih vezanih materijala - novi pogled na obnovu i poboljšanje infrastrukture, Simpozijum Betonske saobraćajnice, Sarajevo, pp. 2-22, 2015.

[3] Giergiczny, Z.: Zašto koristiti beton u izgradnji saobraćajnica? Činjenice i mitovi, Simpozijum Betonske saobraćajnice, Sarajevo, pp. 23-29, 2015.

[4] Gonzalez, M., Tighe, S., Hui, K., Rahman, S., Oliveira Lima, A. Evaluation of freeze/thaw and sacling response of nanoconcrete for Portland Cement Concrete (PCC) pavement, Construction and Building Materials, 120 (2016), pp. 465-472, https://doi. org/10.1016/j.conbuildmat.2016.05.043

[5] Damodar Supe, J., Gupta, M.K.: Flexural Strength - A Measure to Control Quality of Rigid Concrete Pavements, International Journal of Scientific \& Engineering Research, 5 (2014) 11, pp. 46-57.

[6] Sarsam, S.I.: Influence of Nano Materials Addition as Partial Replacement of Cement in the Properties of Concrete Pavement, Journal of Nanoscience and Nanoengineering, 2 (2016) 1, pp. 1-5.

[7] Gonzalez, M., Safiuddin, M., Cao, J., Tighe S.: Sound Absorption and Friction Response of Nano-concrete for Rigid Pavements, Journal of the Transportation Research Board, (2013), pp. 87-94, https:// doi.org/10.3141/2369-10

[8] Lane, D.S.: Evaluation of Concrete characteristics for rigid pavements, Virginia Transportation Research Council, 1998.

[9] Zhang, J., Harvey, J., Ali, A., Roesler, J.: Goal 4 Long Life Pavement Rehabilitation Strategies - Rigid: Laboratory Strength, Shrinkage, and Thermal Expansion of Hydraulic Cement Concrete Mixes, Report prepared for the California Department of Transportation (Caltrans), 2004.

[10] Humpola, B., Bullen, F., Knapton, J.: Quick quality control of concrete block pavers in Australia, The Fifth International Conference on Concrete Block Paving, Tel-Aviv, Israel, pp. 55-64, 1996.

[11] Atis, C.D., Karahan, O., Ari, K., Sola, O.C., Bilim, C.: Relation between Strength Properties (Flexural and Compressive) and Abrasion Resistance of Fiber (Steel and Polypropylene)-Reinforced Fly Ash Concrete, Journal of Materials in Civil Engineering, (2009), pp. 402408, https://doi.org/10.1061/(ASCE)0899-1561(2009)21:8(402)

[12] Atis, C.D., Celik, O.N.: Relation between abrasion resistance and flexural strength of high volume fly ash concrete, Materials and Structures, 35 (2002), pp. 257-260, https://doi. org/10.1617/13827

[13] Krishna Rao, S., Sravana, P., Chandrasekhar Rao, T.: Abrasion resistanceand mechanical properties of Roller Compacted Concrete with GGBS, Construction and Building Materials, 114 (2016), pp. 925-933, https://doi.org/10.1016/j.conbuildmat.2016.04.004
[14] Turk, K., Karatas, M.: Abrasion resistance and mechanical properties of self-compacting concrete with different dosages of fly ash/silica fume, Indian Journal of Engineering \& Materials Sciences, 18 (2011), pp. 49-60.

[15] Gencel, O., Ozel, C., Koksal, F., Erdogmus, E., Martinez-Barrera, G., Brostow, W.: Properties of concrete paving blocks made with waste marble, Journal of Cleaner Production, 21 (2012), pp. 6270.

[16] Aslantas, O.: A study on abrasion resistance of concrete paving blocks, Master thesis, The Graduate school of natural and applied sciences of middle east technical university, 2004.

[17] SRPS B.B2.010: Seperisani agregat (granulat) za beton, Institut za standardizaciju Srbije, Beograd, 1986.

[18] SRPS B.B3.100: Frakcionisani kameni agregat za beton i asfalt, Institut za standardizaciju Srbije, Beograd, 1983.

[19] SRPS U.M1.057: Granulometrijski sastav mešavine agregata za beton, Institut za standardizaciju Srbije, Beograd, 1984.

[20] SRPS B.B8.036: Određivanje količine sitnih čestica metodom mokrog sejanja, Institut za standardizaciju Srbije, Beograd, 1982.

[21] SRPS B.B8.045: Ispitivanje prirodnog i drobljenog agregata mašinom Los Angeles, Institut za standardizaciju Srbije, Beograd, 1978.

[22] SRPS B.B8.044: Ispitivanje postojanosti prema mrazu natrijum sulfatom, Institut za standardizaciju Srbije, Beograd, 1982.

[23] SRPS U.E3.020: Tehnički uslovi za izradu cementnobetonskog kolovoza, Institut za standardizaciju Srbije, Beograd, 1987.

[24] JUS U.M1.020: Određivanje čvrstoće pri pritisku betonskih tela izrađenih od svežeg betona, Institut za standardizaciju Srbije, Beograd, 1993

[25] Grupa autora: Pravilnik za beton i armirani beton 87 - Tom 1 Priručnik, Građevinski fakultet Univerziteta u Beogradu, 1995.

[26] SRPS ISO 4012:2000: Beton-Određivanje čvrstoće epruvete pri pritisku, Institut za standardizaciju Srbije, Beograd, 2000.

[27] JUS U.M1.010: Ispitivanje čvrstoće betona na zatezanju pri savijanju prizmi, Institut za standardizaciju Srbije, Beograd, 1957

[28] SRPS ISO 4013:2000: Beton-Određivanje čvrstoće epruvete pri savijanju, Institut za standardizaciju Srbije, Beograd, 2000.

[29] SRPS B.B8.015: Ispitivanje otpornosti prema habanju brušenjem, Institut za standardizaciju Srbije, Beograd, 1984.

[30] SRPS U.M1.015: Očvrsli beton-Određivanje prodiranje vode pod pritiskom, Institut za standardizaciju Srbije, Beograd, 1998.

[31] SRPS U.M1.016: Ispitivanje otpornosti betona prema dejstvu mraza, Institut za standardizaciju Srbije, Beograd, 1992.

[32] SRPS U.M1.055: Ispitivanje otpornosti površine betona na dejstvo mraza i soli za odmrzavanje, Institut za standardizaciju Srbije, Beograd, 1984. 
[33] Yuan, D., Smith, K., Ansari, F., Gonzalez, C.: Acceptance Criteria of Airfield Concrete Pavement Using Seismic and Maturity Concepts: Appendices, Research Report Innovative Pavement Research Foundation (Skokie), 2006.

[34] Sadati, S., Khayat, K.: Field preformance of concrete pavement incorporating recycled concrete aggregate, Construction and Building Materials, 126 (2016), pp. 691-700.
[35] Tia, M., Kumara, W.: Evaluation of Early Strength Requriement of Concrete for Slab Replacement Using APT, Final Report Department of Civil\&Coastal Engineering, Univeristy of Florida, Gainesville, 2005.

[36] Ghafoori, N., Smith, D.R.: Comparison of ASTM and Canadian Freeze-Thaw Durability Tests, The Fifth Interantional Conference on Concrete Block Paving, Tel-Aviv, Israel, pp. 93-101, 1996. 